\title{
The release of dissolved actinium to the ocean: a global comparison of different end-members
}

Walter Geibert, Matt Charette, Guebuem Kim, Willard S. Moore, Joseph Street, Megan Young, Adina Paytan

Walter Geibert (corresponding author)

previously Alfred Wegener Institute for Polar and Marine Research

now at:

School of GeoSciences, The University of Edinburgh, West Mains Road, Edinburgh EH9 3JW, UK, and the

Scottish Association for Marine Science, Dunstaffnage Marine Laboratory, Dunbeg, Oban, PA37 1QA, UK

Matt Charette

Department of Marine Chemistry and Geochemistry

Woods Hole Oceanographic Institution

Woods Hole, MA 02543, USA

Guebuem Kim

School of Earth \& Environmental Sciences

Seoul National University

Seoul 151-742, Korea

Willard S. Moore

Department of Geological Sciences

University of South Carolina

Columbia, SC 29208

Joseph Street

Department of Geological and Environmental Sciences

Green Earth Sciences, Room 056

Stanford, CA 94305-2115

Megan Young

Isotope Tracers Project

U.S. Geological Survey 
345 Middlefield Road, MS 434

Menlo Park, CA 94025 USA

Adina Paytan

Department of Geological and Environmental Sciences

Stanford University

Stanford CA 94305-2115

Keywords: actinium, radium, submarine groundwater discharge, ocean mixing, continental shelf, global circulation models

\section{Abstract}

The measurement of short-lived ${ }^{223}$ Ra often involves a second measurement for supported activities, which represents ${ }^{227} \mathrm{Ac}$ in the sample. Here we exploit this fact, presenting a set of 284 values on the oceanic distribution of ${ }^{227} \mathrm{Ac}$, which was collected when analyzing water samples for short-lived radium isotopes by the radium delayed coincidence counting system. The present work compiles ${ }^{227} \mathrm{Ac}$ data from coastal regions all over the northern hemisphere, including values from ground water, from estuaries and lagoons, and from marine endmembers. Deep-sea samples from a continental slope off Puerto Rico and from an active vent site near Hawaii complete the overview of ${ }^{227} A c$ near its potential sources.

The average ${ }^{227} \mathrm{Ac}$ activities of nearshore marine end-members range from $0.4 \mathrm{dpm}{ }^{*} \mathrm{~m}^{-3}$ at the Gulf of Mexico to $3.0 \mathrm{dpm}{ }^{*} \mathrm{~m}^{-3}$ in the coastal waters of the Korean Strait. In analogy to ${ }^{228} \mathrm{Ra}$, we find the extension of adjacent shelf regions to play a substantial role for ${ }^{227} \mathrm{Ac}$ activities, although less pronounced than for radium, due to its weaker shelf source. Based on previously published values, we calculate an open ocean ${ }^{227} \mathrm{Ac}$ inventory of 1.35 * $10^{18} \mathrm{dpm}{ }^{227} \mathrm{Ac}_{\mathrm{ex}}$ in the ocean, which corresponds to 37 moles, or $8.4 \mathrm{~kg}$. This implies a flux of $127 \mathrm{dpm}^{*} \mathrm{~m}^{-2 *} \mathrm{y}^{-1}$ from the deep-sea floor. For the shelf regions, we obtain a global inventory of ${ }^{227} \mathrm{Ac}$ of $4.5^{*} 10^{15} \mathrm{dpm}$, which cannot be converted directly into a flux value, as the regional loss term of ${ }^{227} \mathrm{Ac}$ to the open ocean would have to be included.

$A c$ has so far been considered to behave similarly to $\mathrm{Ra}$ in the marine environment, with the exception of a strong Ac source in the deep-sea due to ${ }^{231} \mathrm{~Pa}_{\mathrm{ex}}$. Here, we present evidence of geochemical differences between Ac, which is retained in a warm vent system, and Ra, which is readily released (Moore et al., submitted). Another potential mechanism of producing deviations in ${ }^{227} \mathrm{Ac} /{ }^{228} \mathrm{Ra}$ and daughter isotope ratios from the expected production value of lithogenic material is observed at reducing environments, where enrichment in uranium may occur. The presented data here may serve as a reference for including ${ }^{227} \mathrm{Ac}$ in 
circulation models, and the overview provides values for some end-members that contribute to the global Ac distribution.

\section{Introduction}

Actinium-227 is a naturally occurring radioisotope with a half-life of 21.77 years. It is generated by decay of protactinium-231, which is particularly abundant in deep-sea sediments. Actinium has a prominent source at the deep ocean floor, in conjunction with a half-life in the range of ocean mixing time scales, which makes it particularly useful as a tracer for deep mixing and upwelling studies (Geibert et al., 2002; Nozaki, 1984; Nozaki, 1993). However, very few oceanic Ac profiles have been available so far because its measurement was relatively complex. Thus, compared to other elements, little is known about the marine geochemistry of actinium. Recent progress in the measurement of ${ }^{227} \mathrm{Ac}$ (Shaw and Moore, 2002; Geibert and Vöge, submitted), and an increasing need for wellconstrained vertical oceanic mixing rates (Wunsch, 2000; Huisman et al., 2006) brings ${ }^{227} \mathrm{Ac}$ back into the focus of recent tracer studies, and the understanding of its distribution in the ocean will determine how reliable the derived vertical mixing rates are. A substantial analytical progress is the measurement of ${ }^{227} \mathrm{Ac}$ on comparably small sea water volumes (20$80 \mathrm{~L}$ ), which enables us to reduce the required sampling time and additional equipment drastically (Geibert and Vöge, submitted).

Once the end-members contributing to the ocean are known, ${ }^{227} \mathrm{Ac}$ may serve as a tool to validate mixing coefficients in numerical models. If a model matches the oceanic ${ }^{227} \mathrm{Ac}$ distribution based on given end-member inputs, the relative contributions of lateral and vertical mixing are likely to be close to natural values. This work aims at providing ${ }^{227} \mathrm{Ac}$ concentrations from various potential sources, enabling modellers to include this valuable tracer in model validations.

So far, actinium has been mainly considered to behave in the ocean similarly to radium (Nozaki et al., 1990). Similar distribution coefficients of Ra and Ac in open ocean environments justify this assumption in many cases. However, actinium is expected to resemble the lanthanides in some aspects, like in its affinity for iron hydroxide, while radium is an alkaline earth metal that tends to be less particle reactive, but co-precipitates with barium sulphate. If we compare ${ }^{227} \mathrm{Ac}$ to ${ }^{228} \mathrm{Ra}$ (half-life $5.75 \mathrm{y}$ ), the different geochemical behaviour of the radioisotopes at the beginning of the respective decay chains may also introduce large differences in their distribution. Uranium may accumulate to considerable concentrations in sediments under anoxic conditions, and ${ }^{227} \mathrm{Ac}$ will be generated by ${ }^{235} \mathrm{U}$ via the intermediate isotope ${ }^{231} \mathrm{~Pa}$. ${ }^{228} \mathrm{Ra}$, in contrast, is a decay product of ${ }^{232} \mathrm{Th}$, which is largely unaffected by redox processes. Data presented here shed light on some environments where dissimilarities between actinium and radium may be observed. 
${ }^{228} \mathrm{Ra}$ and ${ }^{227} \mathrm{Ac}$ can in theory both be released from continental shelf and slope sediments (Nozaki and Yang, 1987). For ${ }^{228} \mathrm{Ra}$, a pronounced relationship between its oceanic concentration and the extension of the shelf region that is generating it was found (Rutgers van der Loeff et al., 1995). This effect must be less pronounced for ${ }^{227} \mathrm{Ac}$, because the activity of its sedimentary source ${ }^{231} \mathrm{~Pa}$ increases with depth (average ${ }^{231} \mathrm{~Pa}$ in deep-sea sediments: $2.8 \mathrm{dpm}^{*} \mathrm{~g}-1$; ${ }^{231} \mathrm{~Pa}$ in shelf sediments: $0.1 \mathrm{dpm}^{*} \mathrm{~g}-1$; Yang et al., 1986; Nozaki, 1993). However, a moderate enrichment of ${ }^{227}$ Ac should be observed over extended shelf regions, compared to those with a narrow shelf. Once detached from their source, the activity of both isotopes will change due to dilution and radioactive decay, thus the changing ${ }^{228} \mathrm{Ra} /{ }^{227} \mathrm{Ac}$ ratio could provide a tool for the dating of a water mass, or be used to determine mixing coefficients, on a larger scale than the short-lived radium isotopes ${ }^{223} \mathrm{Ra}$ and ${ }^{224} \mathrm{Ra}$. The ${ }^{227} \mathrm{Ac}$ data from a variety of locations around the globe presented here have been collected through indirect measurement of ${ }^{227} \mathrm{Ac}$, when ${ }^{223}$ Ra excess is determined by delayed coincidence counting (Moore and Arnold, 1996). Consequently, the sample locations were not chosen specifically for ${ }^{227}$ Ac distribution. However, the sample set covers some of the most interesting potential source areas for ${ }^{227} A c$ to the open ocean. While the dataset presented here may serve as a reference for ${ }^{227} A c$ backgrounds when ${ }^{223} \mathrm{Ra} \mathrm{ex}_{\mathrm{ex}}$ is to be measured, it also gives a global overview of the range of Ac activities that can be expected near potential sources, and it is suitable for estimating the influence of ${ }^{227} \mathrm{Ac}$ input from shallow sources and hydrothermal sources onto the open ocean signal, which may be used to calculate vertical mixing coefficients.

\section{Material and Methods}

\subsection{Sampling and Measurement}

Our data collection was produced with the radium delayed coincidence counting (RaDeCC) system (Moore and Arnold, 1996), which is routinely operated for the radiometrical determination of short-lived ${ }^{223} \mathrm{Ra}$ (half-life 11.4 days) and ${ }^{224} \mathrm{Ra}$ (half-life 3.7 days). Sampling usually consists of collecting 20-100 I of seawater, which is slowly $(<1 \mathrm{l} / \mathrm{min})$ passed through manganese-oxide coated acrylic fiber (Moore, 1976). Both Ra and Ac are quantitatively adsorbed onto the fiber (Reid et al., 1979) and can subsequently be measured by emanation of the $\mathrm{Rn}$ isotopes that are generated by the specific decays. The $\mathrm{MnO}_{2}$ may even be a more efficient adsorber for $\mathrm{Ac}$ than for $\mathrm{Ra}$, because reported retention efficiencies on $\mathrm{MnO}_{2}$-coated polypropylene cartridges (Buesseler et al., 1992) as used for large-volume, high flow rate sampling of Ra and Ac are higher for Ac (average 70\%, Geibert et al., 2002) than for Ra (typically 20-30\%). Most applications of the short-lived $\mathrm{Ra}$ isotopes require corrections for supported ${ }^{223} \mathrm{Ra}$ and ${ }^{224} \mathrm{Ra}$, which means subtracting the activities of their respective progenitors ${ }^{227} \mathrm{Ac}$ and ${ }^{228} \mathrm{Th}$. Therefore, the quantification of ${ }^{223} \mathrm{Ra}$ and ${ }^{224} \mathrm{Ra}$ excess 
comprises two counting steps. The first counting is performed as soon as possible after sample collection, the second counting is performed after $>5$ half-lives of ${ }^{223} \mathrm{Ra}$, when all detectable ${ }^{223} \mathrm{Ra}$ and ${ }^{224} \mathrm{Ra}$ on the manganese fiber must be generated by ${ }^{227} \mathrm{Ac}$ and ${ }^{228} \mathrm{Th}$ decay. The second counting therefore provides a value for ${ }^{227} \mathrm{Ac}$. Our work is exploiting the collection of ${ }^{227} \mathrm{Ac}$ data that was produced in different locations where short-lived $\mathrm{Ra}$ isotopes were measured (Figure 1).

\subsection{Sampling locations}

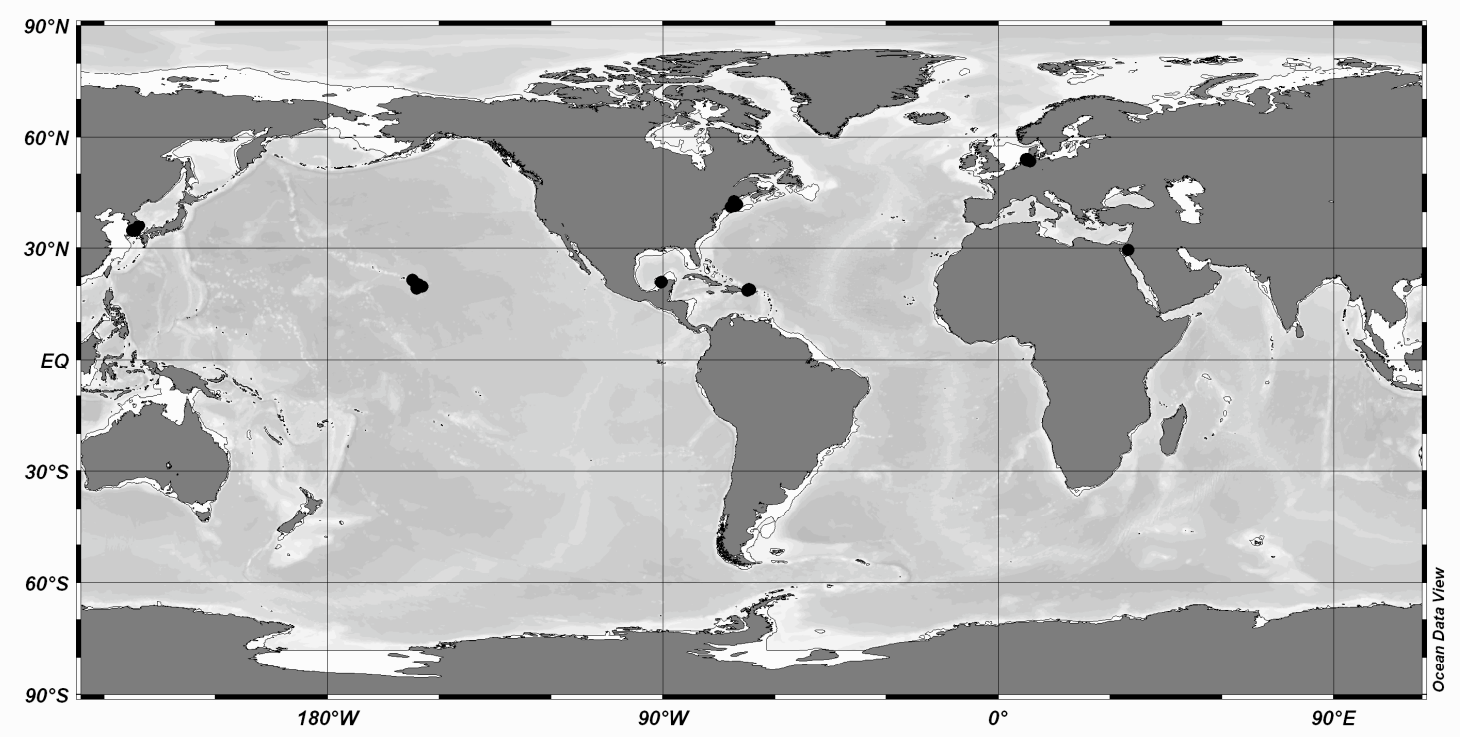

Figure 1: Global map of sample locations

\subsubsection{USA, Massachusetts and Rhode Island}

A collection of samples from different environments, including ground water, is available from the coast of Massachusetts and Rhode Island (Figure 2, Figure 3). The dataset comprises ground water from Waquoit Bay, surface and ground water from Pamet River, water from a seep and surface water from Quonny Pond, and surface and ground water samples from Plum Island. The region is characterized by a large salt-marsh at the interface between the land and ocean, with a gradual change from fresh to saline, and from reducing to oxidizing conditions. At Waquoit Bay, two comprehensive studies have investigated the subterranean estuary and its influence on some trace elements (Charette and Sholkovitz, 2006; Charette et al., 2005). The release of alkaline earth elements to surface water was shown to be not only controlled by salinity increases, but also by reductive dissolution of manganese oxides. $\mathrm{U}$, the ultimate source of ${ }^{227} \mathrm{Ac}$, in contrast, is retained in the reducing pore water environment (Charette and Sholkovitz, 2006). 


\subsubsection{Hawaii}

Two different types of samples were collected in the vicinity of Hawaii (Figure 4). A set of samples was taken in nearshore surface waters, at locations that are influenced by freshwater inputs to various degrees, as seen in the salinities of these samples. For a more detailed description of these sampling locations and the radium data, see (Street et al., submitted). Another set of samples was taken in the deep ocean near Puna ridge, a young volcanic ridge with active warm vents at the sea floor. Additional deep samples were collected away from the ridge. For a more detailed description of the location, the sophisticated sampling techniques, and ${ }^{223} \mathrm{Ra} /{ }^{224} \mathrm{Ra}$ data, see (Moore et al., submitted).

\subsubsection{Yucatan/ Mexico}

Brackish groundwater, lagoon water, and water from the shallow coastal ocean were collected in and around Celestun Lagoon (Figure 5), a shallow coastal lagoon about $20 \mathrm{~km}$ in length located on the north-eastern coast of the Yucatan Peninsula, Mexico. The lagoon is connected to the coastal waters of the Gulf of Mexico by a narrow opening at its southern end, and the coastal waters are $<50 \mathrm{~m}$ deep in the area around Celestun. Most of the samples were collected from transects along the salinity gradient of the brackish lagoon, with some samples taken from the open coastal waters outside of the lagoon. Samples were also collected from two brackish springs with discharge points located near the mid-point of the lagoon, and one sample was collected from a slightly brackish $(S=3.1)$ well located next to Celestun Harbor. For more details see (Young et al., submitted).

\subsubsection{Puerto Rico}

Off the north eastern coast of Puerto Rico, a number of Ac data from deep waters near the sea floor along the slope of the island are presented (Figure 6). In contrast to most other sites shown here, these sample locations are not influenced by release from the continental shelf or freshwater/groundwater mixing effects, but they are representing open ocean values in the vicinity of slope sediments.

\subsubsection{Israel, Gulf of Aqaba}

Samples from the Israeli coast of the Red Sea near Elat (Figure 7) were collected from a variety of settings. They range from sea water samples at the beach to fully marine conditions and include also artificial water channels that drain agricultural and industrial sites. The high salinity of the Red Sea that reaches 40.6 at the Gulf of Aqaba is unique. The area is very dry with no permanent surface runoff. The land-sea interface consists of a sandy beach and a narrow coastal ocean with large coral reefs. A detailed description of the sampling location and saline groundwater discharge estimates based on measurements of ${ }^{223} \mathrm{Ra}$ and ${ }^{224} \mathrm{Ra}$ activities are provided by Shellenbarger et al. (2006). 


\subsubsection{South Korea, Korean Strait}

The samples from South Korea were taken on the southern and eastern coast (Figure 8). To the south, countless islands in a shallow shelf ocean form the majority of the Korean coast. The adjacent ocean is the Korean Strait, which constitutes the connection between the shallow Yellow Sea in the west and the deeper Sea of Japan/Sea of Korea in the east. The Korean Strait is typically less than $50 \mathrm{~m}$ deep in the vicinity of the coast. Submarine groundwater discharge (SGD) has been shown to be an important discharge component for terrestrial runoff at this location (Hwang et al., 2005; Lee and Kim, 2007).

\subsubsection{German Bight of the North Sea}

The North Sea is a shallow part of the Atlantic Ocean. Its boundaries are Great Britain to the west, France, Belgium, Netherlands, and Germany in the South, and Denmark in the East. The North Sea extends northwards approximately to an imaginary line from the Shetland Islands to the Southern tip of Norway, covering an area of approximately $540.000 \mathrm{~km}^{2}$. Its average depth is less than $100 \mathrm{~m}$, and in the German Bight, it is not deeper than $50 \mathrm{~m}$, and mostly even less than $25 \mathrm{~m}$. A unique feature of the southern North Sea coast is the socalled Wadden Sea, which is characterized by extensive mud flats that extend several kilometres towards the open ocean, and are exposed to air with each tidal cycle. Consequently, large current speeds, intense sediment redistribution and an extreme variability in time and space are affecting the distribution of radionuclides at this site. Several large estuary-forming rivers discharge into the North Sea, including the river Weser, which is part of our study. Samples were taken in the Weser estuary, and on a transect to the open North Sea (Figure 9).

\subsection{Errors}

The errors reported for the different locations vary considerably, depending on the original intention of the respective projects. For some of the samples, appropriate error calculations based on counting statistics and error propagation exist (e.g., the errors for the deep water samples are mostly $<10 \%$ ). However, as not all samples were measured with the intention of quantifying ${ }^{227} \mathrm{Ac}$, thus not all data were available with a complete calculation of the associated errors. In order to discard the least precise values, we have excluded from our investigation samples from surface waters with less than 12 counts. Twelve counts imply a relative counting error of

$$
\frac{\sqrt{n}}{n}=\frac{\sqrt{12}}{12}=0.29
$$


It should be noted that the background in the 219 channel used to calculate ${ }^{227} \mathrm{Ac}$ is typically less than 1 count per day, so even a few counts per day in this channel indicate the presence of ${ }^{227} \mathrm{Ac}$. Taking into account the contributions of other parameters to the statistical error (counting efficiencies, background, moisture content of fiber), the error of the data reported here should be considered to be $<35 \%$. Consequently, we report a constant error of $35 \%$ if no error calculations were available. On the one hand, $35 \%$ seems to be a large value, compared to error estimates for more abundant elements. On the other hand, the reported Ac values vary by almost four orders of magnitude between the different locations, which makes a comparison of the data meaningful in spite of the considerable counting error.

\section{Results}

\subsection{Massachusetts and Rhode Island}

The highest ${ }^{227} \mathrm{Ac}$ activities of all samples investigated were found in ground water samples from Plum Island (PI), with values from $22 \pm 2.4$ to $99 \pm 28 \mathrm{dpm}^{*} \mathrm{~m}^{-3}$. Similarly high values were observed in ground water at Waquoit Bay (WB). They ranged from zero to $65 \pm 6.4$ $\mathrm{dpm}^{*} \mathrm{~m}^{-3}$. Ground water at Pamet River (PR), and water from a seep at Quonny Pond (QP) did not reach such extreme ${ }^{227} \mathrm{Ac}$ concentrations (PR: 0.0 - $7.1 \pm 2.4 \mathrm{dpm}^{*} \mathrm{~m}^{-3}$; QP: $1.5 \pm 0.7-$ $6.3 \pm 1.8 \mathrm{dpm}^{*} \mathrm{~m}^{-3}$ ). At Waquoit Bay, the salinity- ${ }^{227} \mathrm{Ac}$ relationship illustrates the nonconservative release of actinium (Figure 3). ${ }^{227} \mathrm{Ac}$ is low when salinity approaches the freshwater end-member, and it is low when salinity approaches the marine end-member. The release of $A c$ to the dissolved phase takes place when saline water meets solid material containing Ac. Figure 3 illustrates this effect by showing the release of ${ }^{227} \mathrm{Ac}$ after the penetration of saline water into the freshwater aquifer, after a very dry period.

The brackish surface water from PI displays highly variable ${ }^{227} A c$ contents $\left(0.6 \pm 0.1 \mathrm{dpm} \mathrm{m}^{-3}\right.$ - $24.2 \pm 3.9 \mathrm{dpm}^{*} \mathrm{~m}^{-3}$ ). The high variability however is not directly related to changes in salinity. At PR, surface water values range from 0 to $10.9 \mathrm{dpm}^{*} \mathrm{~m}^{-3}$. At $\mathrm{QP},{ }^{227} \mathrm{Ac}$ in surface water is lower $\left(0.09 \pm 0.02-1.7 \pm 0.3 \mathrm{dpm}^{*} \mathrm{~m}^{-3}\right.$ ) and quite constant (average $0.86 \pm 0.46 \mathrm{dpm}$ $\left.{ }^{*} \mathrm{~m}^{-3}, \mathrm{n}=13\right)$.

Summarizing our observations, the ${ }^{227} \mathrm{Ac}$ data from Massachusetts and Rhode Island salt marsh area cover a range of conditions from freshwater to fully saline conditions, and from groundwater end-members to surface waters. The extremely high values $>10 \mathrm{dpm}^{*} \mathrm{~m}^{-3}$ remain in most cases restricted to groundwater. However, some high ${ }^{227}$ Ac activities $>2$ $\mathrm{dpm}^{*} \mathrm{~m}^{-3}$ are observed in surface water data, in particular at $\mathrm{PI}$, which points to the possibility that ${ }^{227} \mathrm{Ac}$ from this source might reach the open ocean in detectable amounts. 

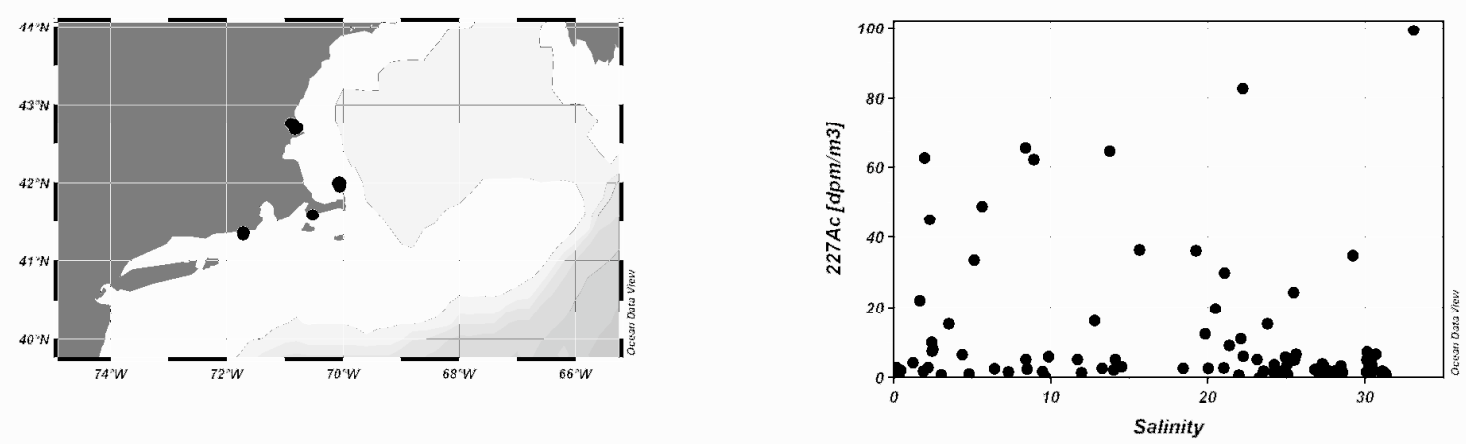

Figure 2: Sample locations and salinity-actinium relationship for the data collection from Massachusetts and Rhode Island. The solid line in the map designates the $100 \mathrm{~m}$ isobath.

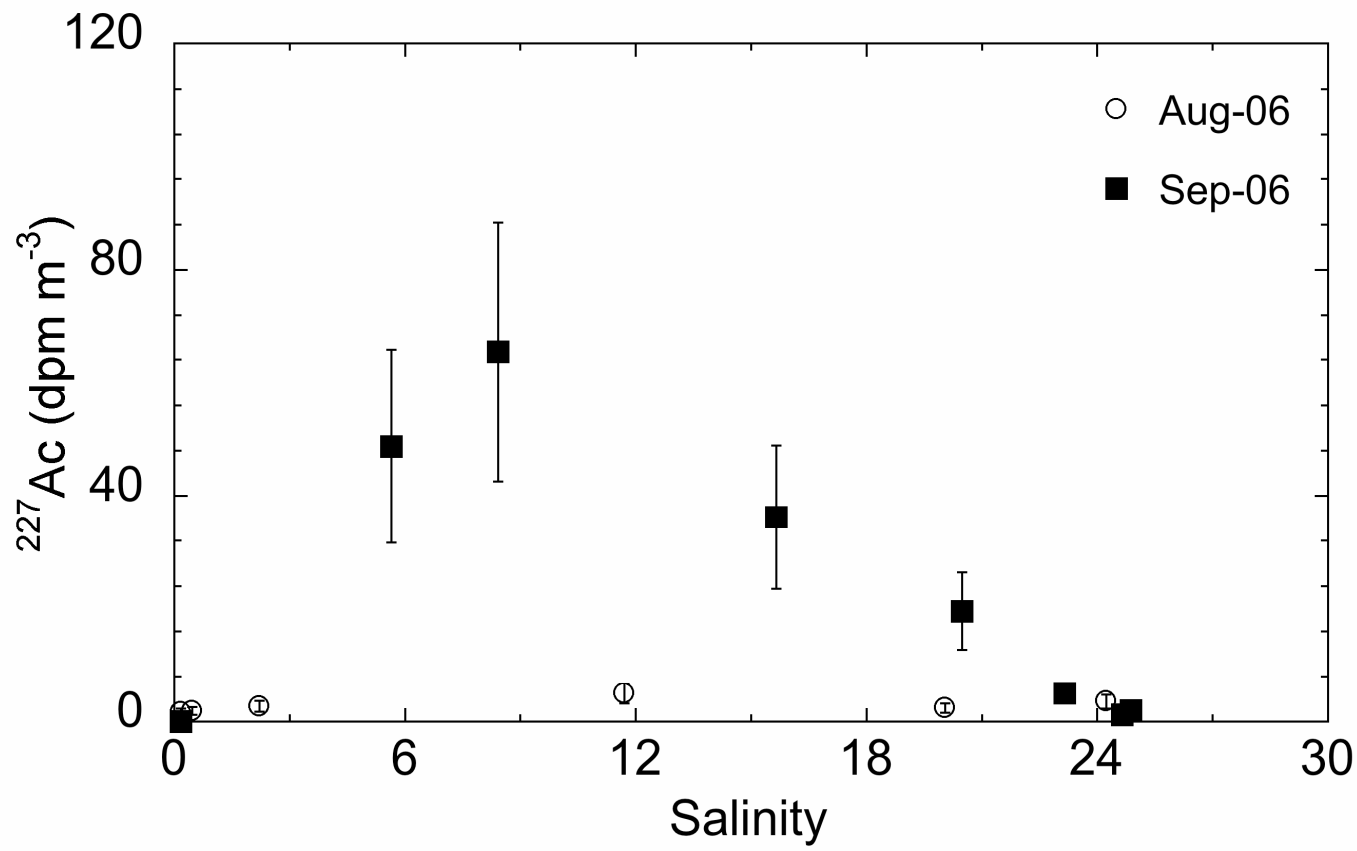

Figure 3: ${ }^{227} \mathrm{Ac}$ in pore water at Waquoit Bay for August and September 2006, shown with its relationship to salinity. During each time period, samples were collected over $\sim 1$ hour from fixed well points at midtide. Sampling was performed during the same phase of the tide in each month. The period between the two samplings was extremely dry, leading to seawater intrusion into the aquifer, which resulted in a large Ac release from the aquifer sediments.

\subsection{Hawaii}

\subsubsection{Coastal waters}

${ }^{227} \mathrm{Ac}$ activities in the samples collected from Hawaii are relatively low $\left(<2 \mathrm{dpm}^{*} \mathrm{~m}^{-3}\right)$ compared to the marshes mentioned above. Five nearshore samples, all with a clear freshwater influence as seen in their salinities, reveal moderate activities of ${ }^{227} \mathrm{Ac}$, ranging from $0.4-1.4 \mathrm{dpm}^{*} \mathrm{~m}^{-3}$. Three samples from enclosed systems (Honokohau Harbor, 
Keauhou Bay) are not substantially higher in ${ }^{227} \mathrm{Ac}\left(0.5-1.9 \mathrm{dpm}{ }^{*} \mathrm{~m}^{-3}\right)$. For comparison with Ra activities see Street et al., submitted.
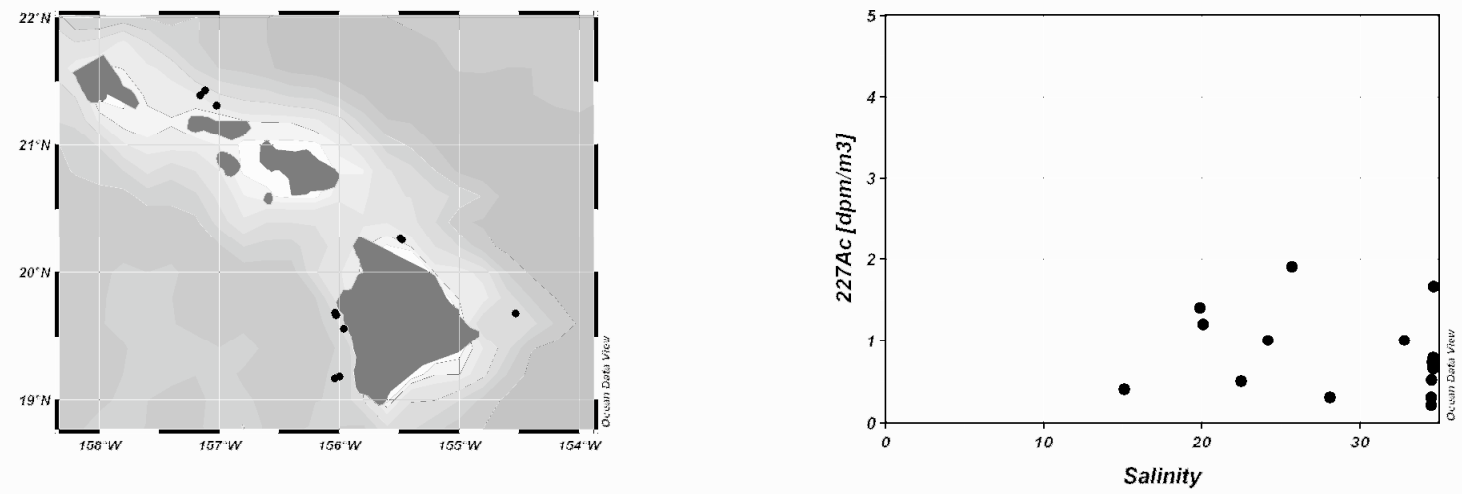

Figure 4: Sample locations and salinity-actinium relationship for the data collection from Hawaii. Deep water samples can be identified by their constantly high salinities. Note the different scale for ${ }^{227} \mathrm{Ac}$.

\subsubsection{Vent sites}

${ }^{227}$ Ac activities in samples collected above the volcanic Puna Ridge, where active warm vents occur, are not elevated compared to samples collected away from the ridge and common deep-sea values. While the effect of bedrock-seawater exchange is clearly seen in short-lived $\mathrm{Ra}$ isotopes (Moore et al., submitted), ${ }^{227} \mathrm{Ac}$ ranging from $0.21-1.66 \mathrm{dpm}^{*} \mathrm{~m}^{-3}$ (1099 $\mathrm{m}$ to $3458 \mathrm{~m}$ ) does not indicate any impact of water percolating in the volcanic bedrock on ${ }^{227}$ Ac concentrations.

\subsection{Yucatan}

The samples from Celestun were mostly taken in a semi-enclosed lagoon that is connected to the shallow coastal ocean by a narrow opening. Both fresh and brackish groundwater discharges directly into the lagoon, and salinities within the lagoon range from 14 to 36 . Salinities range from 30 to 38 in the coastal waters outside the lagoon. The highest actinium activities are measured in the brackish groundwater springs ( 4 to $41.2 \mathrm{dpm}^{*} \mathrm{~m}^{-3}$ ) and brackish well $\left(11 \mathrm{dpm}^{*} \mathrm{~m}^{-3}\right)$. Actinium activities within the lagoon water range from 0.4 to $7 \mathrm{dpm}^{*} \mathrm{~m}^{-3}$. Outside the lagoon, in coastal waters, the activity is low, ranging from 0.2 to $0.6 \mathrm{dpm}^{*} \mathrm{~m}^{-3}$ indicating that the high activities from the lagoon do not impact the oceanic ${ }^{227} \mathrm{Ac}$ concentrations significantly. 

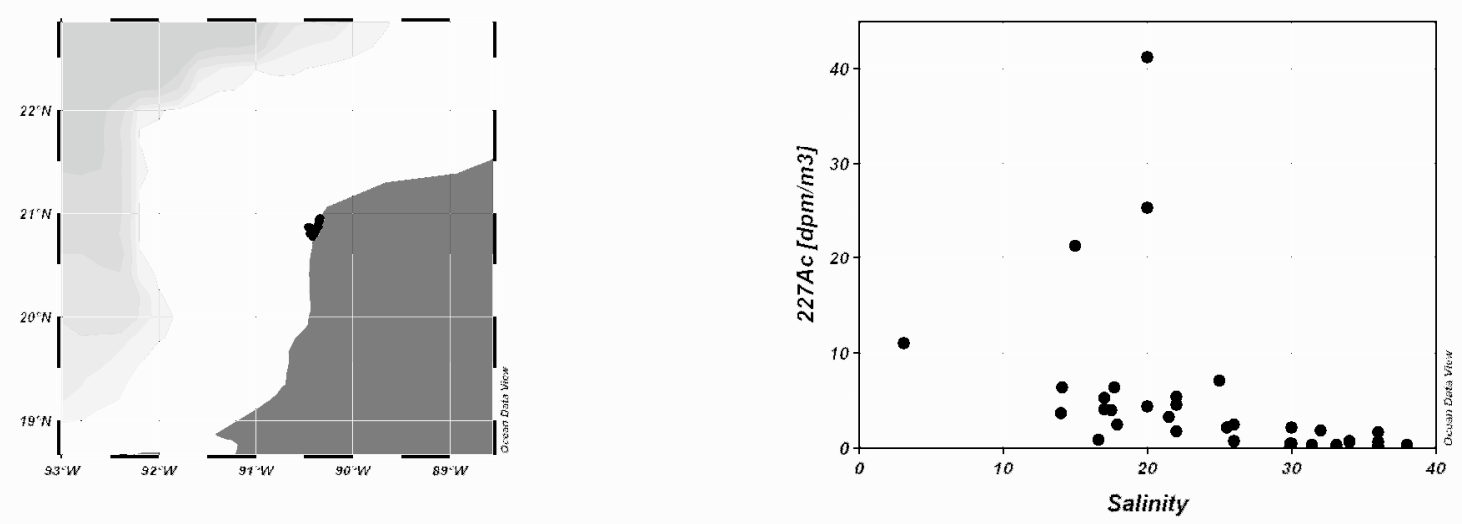

Figure 5: Map of sample locations at the north western shore of Yucatan, Mexico, and the corresponding salinity-actinium relationship.

\subsection{Puerto Rico}

From the northern slope of Puerto Rico, a set of open ocean samples from various depths is available. The activities of ${ }^{227} \mathrm{Ac}$ in three samples from the sea surface range from 0.13-0.25 $\mathrm{dpm}^{*} \mathrm{~m}^{-3}$. Eight deep water samples (700-3289 $\mathrm{m}$ depth) close to the slope display very low activities that are slightly increasing with depth $\left(0.16-0.45 \mathrm{dpm}^{*} \mathrm{~m}^{-3}\right)$.
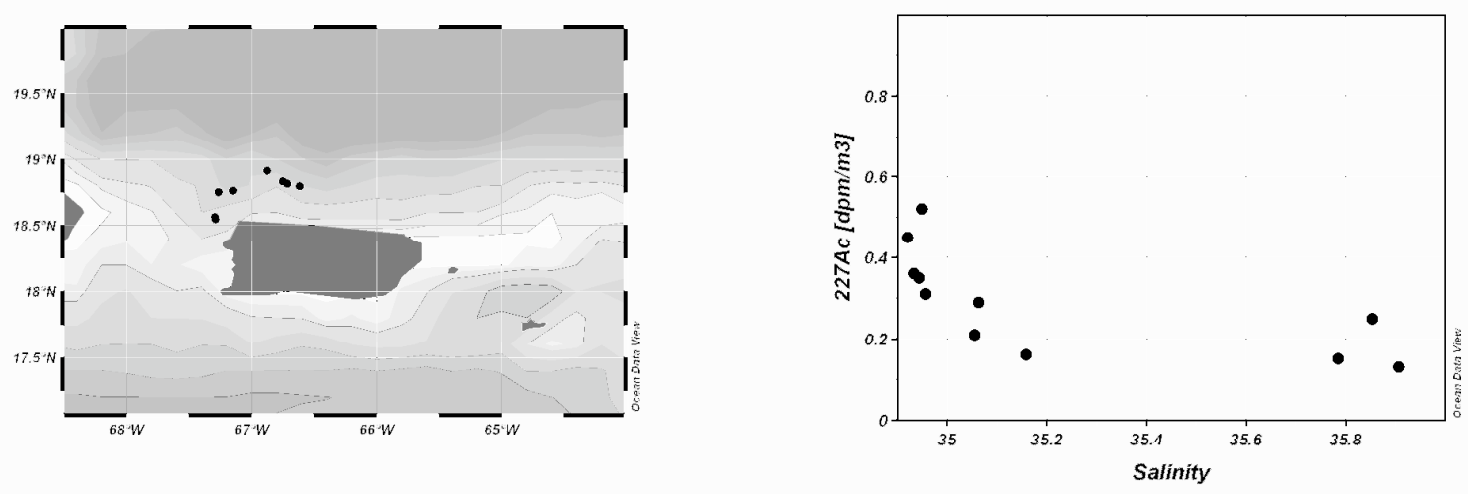

Figure 6: Map of sample locations off Puerto Rico, and the corresponding salinity-actinium relationship. The scales of both salinity and actinium were adapted to fit the small variations in the deep sea.

\subsection{Israel, Gulf of Aqaba}

Most samples from the coast of the Red Sea near Elat were taken close to the beach. The desert area surrounding Elat is characterised by a lack of precipitation throughout most of the year. Seawater salinities exceed 40 , values below that threshold must be considered to have a freshwater influence, which is most likely of anthropogenic origin. Excluding the data with anthropogenic influence, the ${ }^{227} \mathrm{Ac}$ values range from 0.0 to $10.2 \mathrm{dpm}^{*} \mathrm{~m}^{-3}$, with a mean of 1.3 $\pm 1.9 \mathrm{dpm}^{*} \mathrm{~m}^{-3}(\mathrm{n}=77)$. The values in the artificial water channels reach up to $18.9 \mathrm{dpm}{ }^{*} \mathrm{~m}^{-3}$. They were also found to contain very high radium activities (Shellenbarger et al., 2006). A 
possible explanation could be the influence of phosphorous containing fertilizer, which is known to carry elevated activities of uranium and thorium series isotopes.
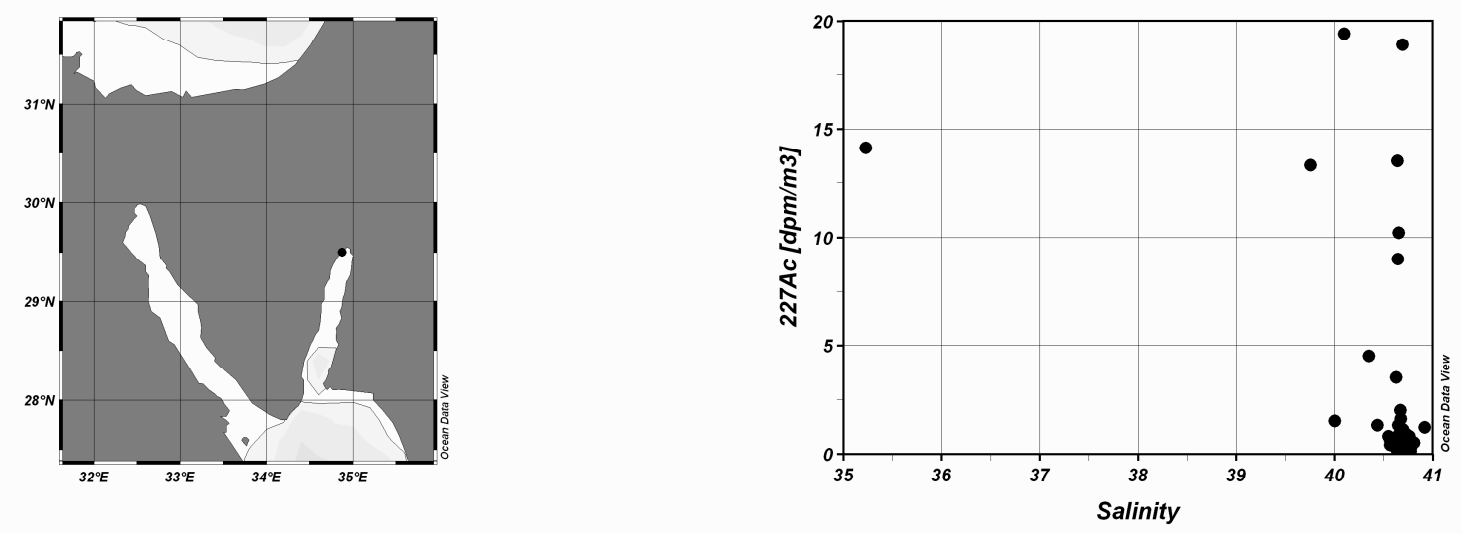

Figure 7: Map of sample locations in the Gulf of Aqaba, Red Sea, and the corresponding salinity-actinium relationship.

\subsection{South Korea, Korean Strait}

The salinities of the samples from the South Korean coast range from 7.69 to 33.51 , representing brackish to fully marine conditions. Highest ${ }^{227} \mathrm{Ac}\left(17 \pm 1.8 \mathrm{dpm}^{*} \mathrm{~m}^{-3}\right)$ is found here with the lowest salinity at a location with riverine input, while the lowest value is $2 \pm 0.3$ $\mathrm{dpm}{ }^{*} \mathrm{~m}^{-3}$. The average of all samples is $5.8 \pm 4.8 \mathrm{dpm}{ }^{*} \mathrm{~m}^{-3}(\mathrm{n}=17)$, which is considerably higher that in other coastal regions.
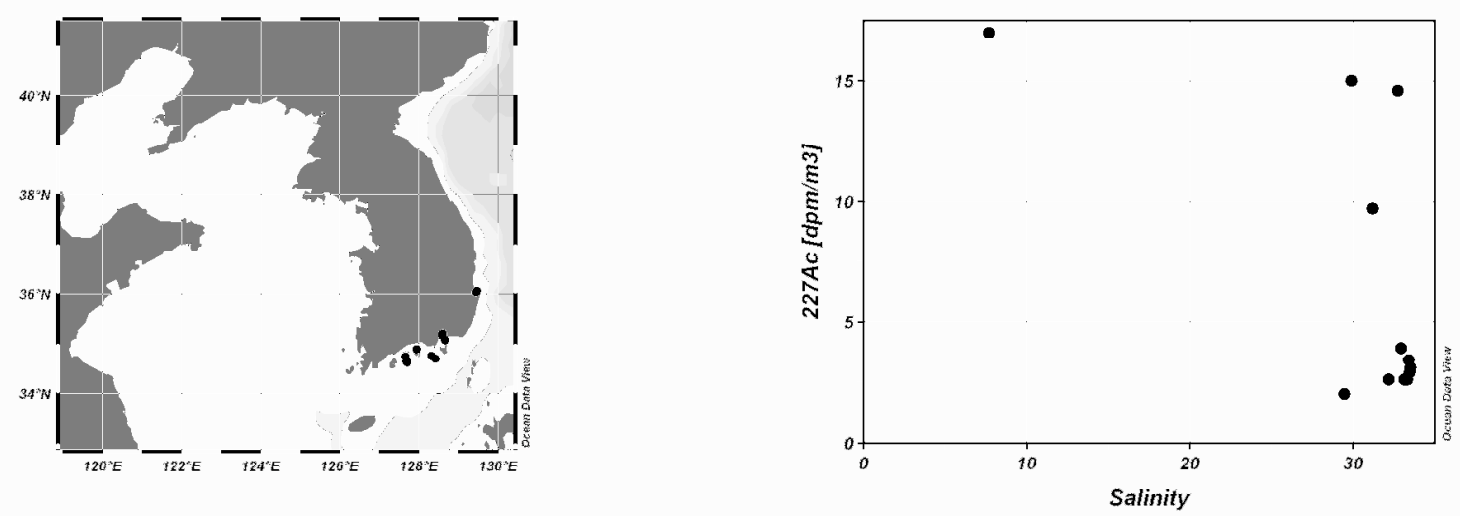

Figure 8: Map of sample locations off South Korea, and the corresponding salinity-actinium diagram.

\subsection{North Sea}

In the North Sea region, samples from two different regimes are available. Values from fully marine conditions decrease from the tidally flooded mud flat with $1.77 \mathrm{dpm}{ }^{*} \mathrm{~m}^{-3}$ to $0.17 \mathrm{dpm}$ ${ }^{*} \mathrm{~m}^{-3}$ in the open North Sea. In a nearby estuary that discharges into the North Sea, higher activities are observed, which vary with the tide from 0.43 to $4.86 \mathrm{dpm}{ }^{*} \mathrm{~m}^{-3}$. 

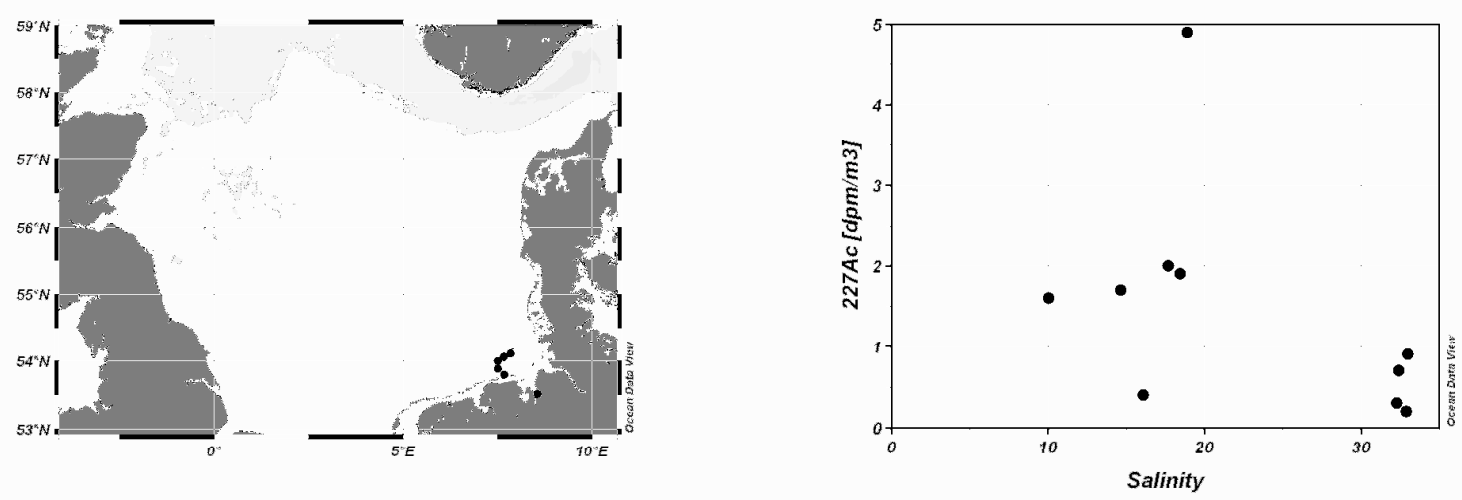

Figure 9: Sample locations in the German Bight of the North Sea, and the corresponding salinity-actinium diagram. Salinities $<20$ indicate values from an estuary.

\subsection{Global}

From a global perspective, ${ }^{227}$ Ac values range from below $0.1 \mathrm{dpm}^{*} \mathrm{~m}^{-3}$ in shallow open ocean conditions to $99 \pm 28 \mathrm{dpm}^{*} \mathrm{~m}^{-3}$ in ground water. Typical coastal values, as compiled in Table 1, are in the range from 0.1 to $1.5 \mathrm{dpm}^{*} \mathrm{~m}^{-3}$. In the Korean Strait, with a large neighbouring shelf region, average coastal activities reach $3.0 \mathrm{dpm}^{*} \mathrm{~m}^{-3}$ (Table 1). Under special conditions (enclosed locations, estuaries, seeps, pronounced SGD), up to $50 \mathrm{dpm}$ * $\mathrm{m}^{-3}$ can be expected.

\section{Discussion}

\subsection{Deep sea}

In order to assess the observed ${ }^{227}$ Ac values near some potential sources in a global context, we first need to estimate the concentration, the inventory and the flux of ${ }^{227} \mathrm{Ac}$ from the deepsea floor in the open ocean. For that purpose, we provide here a compilation of four selected ${ }^{227}$ Ac profiles from Nozaki (1984) and Geibert et al. (2002) that we believe to represent average open ocean conditions. Based on this distribution, as shown in Figure 10, we calculate an inventory of ${ }^{227} \mathrm{Ac}$ for the ocean, and a corresponding flux. Mean ${ }^{227} A c_{e x}$ activities for $1000 \mathrm{~m}$-intervals are shown in

Table 1: Overview of average ${ }^{227}$ Ac activities of the coastal marine end member. Included are all near shore, near surface values for which salinity values were available and $>30$, and where no obvious anthropogenic influence was observed. The average at the bottom of the table was calculated from the regional averages, in order to avoid over-representation of areas with intense sampling.

\begin{tabular}{|l|l|l|l|}
\hline Location & $\begin{array}{l}\text { Average } \\
{ }^{227} \text { Ac }\left[\mathrm{dpm}^{* m}-\right.\end{array}$ & Standard & Deviation \\
& $\left.{ }^{3}\right]$ & & \\
\hline
\end{tabular}




\begin{tabular}{|l|l|l|l|}
\hline $\begin{array}{l}\text { Massachusetts } \\
\text { and Rhode } \\
\text { Island, QP }\end{array}$ & 0.9 & 0.46 & 13 \\
\hline $\begin{array}{l}\text { Massachusetts } \\
\text { and Rhode } \\
\text { Island, PR }\end{array}$ & 1.4 & - & 1 \\
\hline Hawaii & 1.0 & - & 1 \\
\hline $\begin{array}{l}\text { Yucatan, } \\
\text { Celestun }\end{array}$ & 0.4 & 0.2 & 8 \\
\hline Israel, Elat & 1.4 & 2.2 & 34 \\
\hline $\begin{array}{l}\text { South Korea, } \\
\text { Korean Strait }\end{array}$ & 3.0 & 0.6 & 12 \\
\hline $\begin{array}{l}\text { Germany, } \\
\text { North Sea }\end{array}$ & 0.5 & 0.3 & 4 \\
\hline Average & 1.2 & 0.8 & 7 (regions) \\
\hline
\end{tabular}

Table 2, where the index "ex" denotes excess activities, which are corrected for contributions from ${ }^{231} \mathrm{~Pa}$ in the water column. This correction is less obligatory for coastal and surface values, where dissolved ${ }^{231} \mathrm{~Pa}$ can be expected to contribute only a negligible fraction of ${ }^{227} \mathrm{Ac}$. For deep ocean values, however, only ${ }^{227} \mathrm{Ac}$ ex can be considered to be supplied from the seafloor.

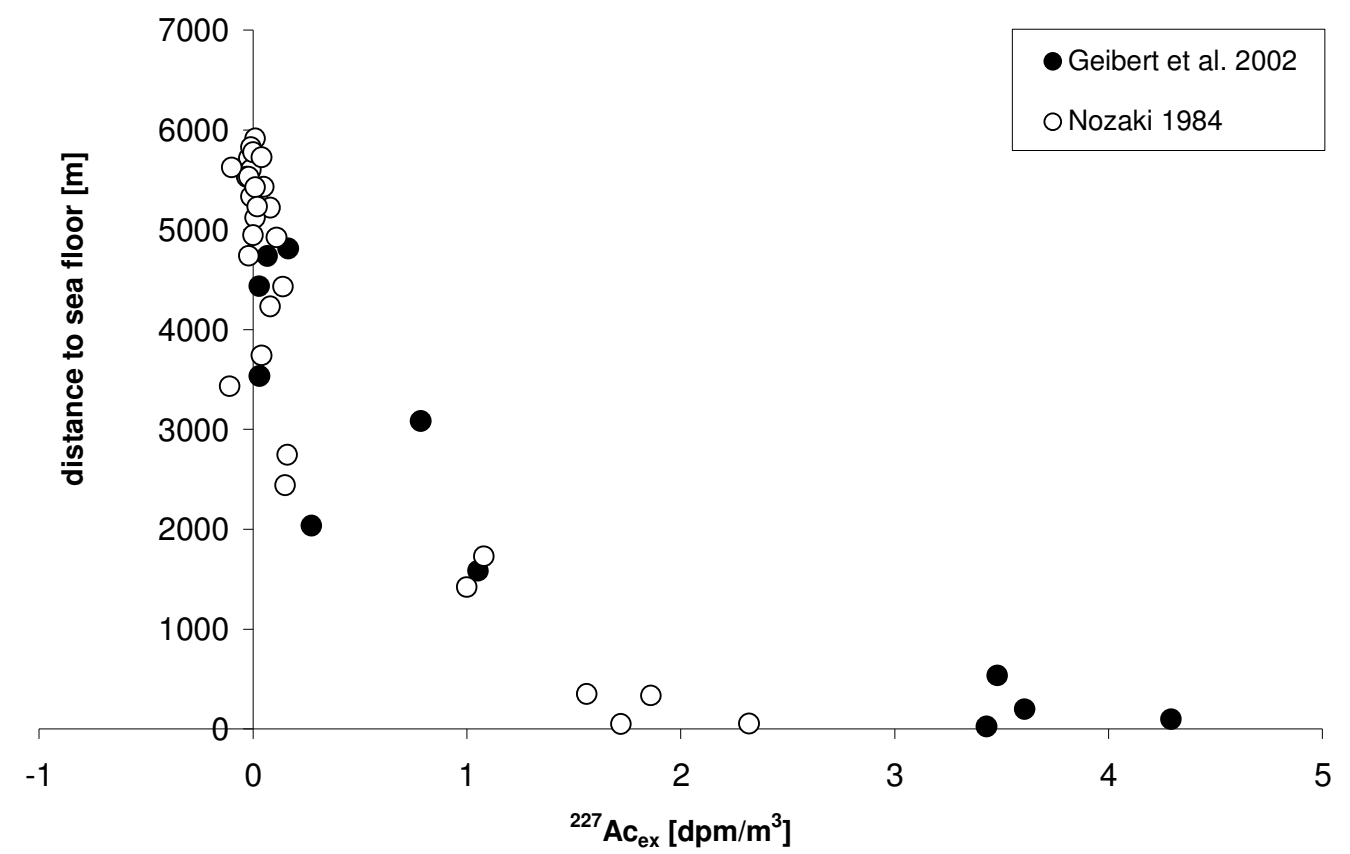

Figure 10: The relationship between 227Acex in open ocean regions, and the distance from the deep-sea floor, illustrated with four typical profiles. 
Assuming an average depth of the oceans of approximately $4000 \mathrm{~m}$, we obtain an average ${ }^{227}$ Ac activity of $1.0 \mathrm{dpm}{ }^{*} \mathrm{~m}^{-3}($

Table 1: Overview of average ${ }^{227}$ Ac activities of the coastal marine end member. Included are all near shore, near surface values for which salinity values were available and $>30$, and where no obvious anthropogenic influence was observed. The average at the bottom of the table was calculated from the regional averages, in order to avoid over-representation of areas with intense sampling.

\begin{tabular}{|l|l|l|l|}
\hline Location & $\begin{array}{l}\text { Average } \\
{ }^{227} \mathrm{Ac}\left[\mathrm{dpm}^{\star \mathrm{m}} \text { - }\right. \\
\left.{ }^{3}\right]\end{array}$ & $\begin{array}{l}\text { Standard } \\
\text { Deviation }\end{array}$ & $\mathrm{n}$ \\
\hline $\begin{array}{l}\text { Massachusetts } \\
\text { and Rhode } \\
\text { Island, QP }\end{array}$ & 0.9 & 0.46 & 13 \\
\hline $\begin{array}{l}\text { Massachusetts } \\
\text { and Rhode } \\
\text { Island, PR }\end{array}$ & 1.4 & - & 1 \\
\hline $\begin{array}{l}\text { Hawaii } \\
\text { Yucatan, } \\
\text { Celestun }\end{array}$ & 0.4 & 0.2 & 8 \\
\hline Israel, Elat & 1.4 & - & 1 \\
\hline $\begin{array}{l}\text { South Korea, } \\
\text { Korean Strait }\end{array}$ & 3.0 & 0.6 & 12 \\
\hline $\begin{array}{l}\text { Germany, } \\
\text { North Sea }\end{array}$ & 0.5 & 0.3 & 4 (regions) \\
\hline Average & 1.2 & 0.8 & 34 \\
\hline
\end{tabular}

Table 2). We do not take into account here the lower volume of the deepest $1000 \mathrm{~m}$ interval compared to the uppermost intervals, as our deepest interval has to include all ${ }^{227} \mathrm{Ac}$ from $>4000 \mathrm{~m}$ water depth. The total inventory of ${ }^{227} \mathrm{Ac}$ can be calculated by multiplying the activity with an approximate volume of the oceans of $1.35^{*} 10^{9} \mathrm{~km}^{3}(4000 \mathrm{~m}$ * ocean surface, according to Gierloff-Emden, 1980). We obtain a total activity of $1.35^{*} 10^{18} \mathrm{dpm}^{227} \mathrm{Ac}_{\mathrm{ex}}$ in the ocean, which corresponds to 37 moles or $8.4 \mathrm{~kg}$. Given the decay constant of ${ }^{227} \mathrm{Ac}$, we can convert the inventory into a steady state flux, with the equation

$$
\mathrm{J}=\mathrm{I}^{*} \lambda
$$


where $\mathrm{J}$ designates the flux, I the inventory, and $\lambda$ represents the decay constant. Based on an inventory of $4000 \mathrm{dpm}^{*} \mathrm{~m}^{-2}$, we obtain a vertical flux of ${ }^{227} \mathrm{Ac}$ from the deep sea floor of $127 \mathrm{dpm}^{*} \mathrm{~m}^{-2 *} \mathrm{y}^{-1}$.

\subsection{Coastal ocean}

A similar calculation can be performed for the continental shelf areas, based on the ${ }^{227} \mathrm{Ac}$ activities in coastal waters (Table 1). With an average activity on the shelf of $1.5 \mathrm{dpm}{ }^{*} \mathrm{~m}^{-3}$, and assuming an extension of the shelves of approximately $0.228 * 10^{14} \mathrm{~m}^{2}$ with an average water depth of $132 \mathrm{~m}$ (Gierloff-Emden, 1980), the inventory amounts to $4.5^{*} 10^{15} \mathrm{dpm}$ $\left(157 \mathrm{dpm}^{*} \mathrm{~m}^{-2}\right)$. This rough estimate implies a flux of $5.0 \mathrm{dpm}^{*} \mathrm{~m}^{-2 *} \mathrm{y}^{-1}$. However, this value must constitute the lower boundary for actual ${ }^{227} \mathrm{Ac}$ fluxes, as we neglect ${ }^{227} \mathrm{Ac}$ losses to the open ocean in this calculation. For example if the average residence time of coastal waters with respect to exchange with the deep ocean is 0.1 years, the shelf flux must be increased a factor of 10. Exchange with the open ocean must be an important loss term in the budget of ${ }^{227} \mathrm{Ac}$, as illustrated by the elevated activities in the Korean Strait. This region, connected to the Yellow Sea, which is a shallow shelf ocean, accumulates five-fold ${ }^{227}$ Ac higher activities compared to areas that exchange more readily with the open ocean. While the actual fraction of Yellow Sea water (YSW) in the samples off South Korea is small, the ${ }^{227} \mathrm{Ac}$ contribution from this source may be significant. For ${ }^{228} \mathrm{Ra}$, which is well known to accumulate in shelf waters, Kim et al., 2005 report activities of about $500 \mathrm{dpm}^{*} \mathrm{~m}^{-3}$. If the actinium content in YSW was only $1 / 30$ th of the ${ }^{228} \mathrm{Ra}$ value (assuming ${ }^{232} \mathrm{Th} /{ }^{238} \mathrm{U}=1.5$ and ${ }^{238} \mathrm{U} /{ }^{235} \mathrm{U}=20$ ), ${ }^{227} \mathrm{Ac}$ in YSW could reach $17 \mathrm{dpm}^{*} \mathrm{~m}^{-3}$, which would explain elevated ${ }^{227} \mathrm{Ac}$ even in waters that obtain just a small fraction of YSW.

While the open ocean constitutes an important loss term for ${ }^{227} \mathrm{Ac}$ on the shelf, the flux from the shelf will most likely not have a large effect on open ocean concentrations because the global volume of the shelf ocean is very small compared to the open ocean regions.

Exceptions might occur where surface waters come from a shallow coastal ocean with long residence times, like e.g. the Siberian shelves (Rutgers van der Loeff et al., 1995).

\section{3. $\quad{ }^{227} \mathrm{Ac}$ in ground water and pore water}

Nozaki et al. (1990) were the first to report pore water activities of ${ }^{227} \mathrm{Ac}$. They analyzed samples from a box core taken in the Northwest Pacific at $5270 \mathrm{~m}$ depth. They could show a ${ }^{227} \mathrm{Ac}$ depletion at the surface of the sediment, which corresponds to its release to the deep ocean. At sediment depths $>10 \mathrm{~cm}$, they observed ${ }^{227} \mathrm{Ac}$ pore water values in equilibrium with the surrounding solid phase of about $100 \mathrm{dpm}^{*} \mathrm{~m}^{-3}\left(57-131 \mathrm{dpm}^{*} \mathrm{~m}^{-3}\right)$, at ${ }^{231} \mathrm{~Pa}$ activities in 
the solid phase of $1.4 \mathrm{dpm} / \mathrm{g}$. These concentrations closely resemble our data from saline groundwater at Waquoit Bay.

This fact is surprising, as ${ }^{227} \mathrm{Ac}$ concentrations must be expected to be controlled by the activity of its progenitor, ${ }^{231} \mathrm{~Pa}$. For shelf sediments, we can typically expect ${ }^{231} \mathrm{~Pa}$ activities of $0.1 \mathrm{dpm} / \mathrm{g}$ (Nozaki, 1993), while deep-sea sediments have an average activity of $2.8 \mathrm{dpm} / \mathrm{g}$ (Yang et al., 1986). The actual release of ${ }^{227} \mathrm{Ac}$ to the pore water is further affected by the location of ${ }^{231} \mathrm{~Pa}$ atoms in the mineral structure upon decay, in analogy to ${ }^{226} \mathrm{Ra}$ release by ${ }^{230} \mathrm{Th}$ (Cochran and Krishnaswami, 1980). ${ }^{231} \mathrm{~Pa}_{\mathrm{ex}}$, bound to sediment grains by sorption, constitutes the main ${ }^{231} \mathrm{~Pa}$ fraction in deep-sea sediments. It is released more readily than ${ }^{231} \mathrm{~Pa}$ in shelf sediments, which will mostly be found within the crystal lattice (Geibert et al., 2002). If we observe ${ }^{227} \mathrm{Ac}$ activities in coastal saline groundwater that are comparable to deep-sea sediments with a ${ }^{231} \mathrm{~Pa}$ content of $1.4 \mathrm{dpm} / \mathrm{g}$, this requires either unusually high ${ }^{231} \mathrm{~Pa}$ activities in shelf sediments, or far lower distribution coefficient between solution and particles than reported from other locations. Indeed, there is a mechanism that could explain very high ${ }^{231} \mathrm{~Pa}$ in the coastal aquifers in Massachusetts. Charette et al. (2005) report a mechanism of uranium enrichment in the reducing pore water environment at Waquoit Bay. ${ }^{235} \mathrm{U}$, as the ultimate source of ${ }^{227} \mathrm{Ac}$, is enriched in the sediment grains that surround the pore water or ground water at Waquoit Bay and neighbouring locations. This leads to an increased concentration of ${ }^{231} \mathrm{~Pa}$, which must be comparable to deep-sea values. If this explanation holds true, anomalously high ${ }^{227} \mathrm{Ac} /{ }^{228} \mathrm{Ra}$ in the pore water would be expected, because ${ }^{228} \mathrm{Ra}$ is a decay product of the ${ }^{232}$ Th series, and ${ }^{232}$ Th should be much less affected by the local redox conditions. Alternatively, the values observed in Waquoit Bay groundwater may not be elevated year round, but rather part of a seasonal cycle whereby Ac is loaded onto freshwater sediments during wet periods, then desorbed to brackish groundwater when seawater intrudes into the aquifer during dry periods (Figure 3;Gonneea et al., 2007). Regardless, the high concentrations of ${ }^{227} \mathrm{Ac}$ in the ground water samples do not necessarily imply high ${ }^{227} \mathrm{Ac}$ fluxes to the surrounding environment. Our present data do not allow quantitative conclusions on the importance of this mechanism for ${ }^{227} A c$ fluxes.

\subsection{Release from slope sediments and vent sites}

Nozaki and Yang (1987) reported some evidence for ${ }^{227}$ Ac release from a continental slope in the Western North Pacific. They found elevated ${ }^{227} \mathrm{Ac}$, measured as ${ }^{227} \mathrm{Th}$ of up to 1.0 $\mathrm{dpm}^{*} \mathrm{~m}^{-3}$ even in depths $<2000 \mathrm{~m}$ in some of their samples, which they considered to be unaffected by upwelling. Our eight deep water samples from Puerto Rico (700- 3289 m depth) do not support the hypothesis that slope sediments serve as a ${ }^{227} \mathrm{Ac}$ source everywhere. Total ${ }^{227} \mathrm{Ac}$ activities are $0.16-0.45 \mathrm{dpm}{ }^{*} \mathrm{~m}^{-3}$, and ${ }^{227} \mathrm{Ac}_{\mathrm{ex}}$ will be close to zero, as ${ }^{231} \mathrm{~Pa}$ in deep waters (not measured here) contributes typically $0.1-0.5 \mathrm{dpm}^{*} \mathrm{~m}^{-3}$ to the ${ }^{227} \mathrm{Ac}$ 
signal. This means that continental slopes are not releasing ${ }^{227} \mathrm{Ac}$ to the deep ocean everywhere.

From the systems near Hawaii, where sea-water circulates in recently formed basalt, just a few values are available. Combining these observations with the observations of Moore et al. (submitted), we can learn about the specific geochemical properties of ${ }^{227} \mathrm{Ac}$. The chemical composition of seawater, including isotopes of the U-Th series, is known to be altered considerably when interacting with basaltic bedrock. The resulting radioactive disequilibrium has been shown to be a powerful tool to gain insight into this hardly accessible system by selective retention or release of isotopes with different half-lives (Kadko, 1996). ${ }^{227} \mathrm{Ac}$ is found to display the activities of ambient seawater near the vent sites, while short-lived $\mathrm{Ra}$ isotopes, especially ${ }^{223} \mathrm{Ra}$, are strongly enriched (Moore et al., submitted). This observation points to a pronounced difference in the behaviour of actinium and radium during water circulation in the bedrock. Moore et al. (submitted) conclude from the elevated ${ }^{223} \mathrm{Ra}$ concentrations that ${ }^{231} \mathrm{~Pa}$ is retained in the volcanic bedrock when the seawater percolates through the basaltic seafloor. This ${ }^{231} \mathrm{~Pa}$ decays to ${ }^{227} \mathrm{Ac}$, which is obviously also retained in the system. Otherwise, the decay chain would break here and no ${ }^{223}$ Ra could be produced. ${ }^{223} \mathrm{Ra}$, in contrast, is released to the warm circulating fluids. If the bedrock was accumulating ${ }^{230} \mathrm{Th}$ in the same way as ${ }^{231} \mathrm{~Pa}$, exchange between the solid seafloor and the water column could also contribute to the oceanic ${ }^{226} \mathrm{Ra}$ inventory. This applies especially to mid-ocean ridge systems that have been active for longer periods than the Puna ridge (700-2500 years, Moore et al., submitted), allowing the build-up of substantial ${ }^{231} \mathrm{~Pa}$ and ${ }^{230} \mathrm{Th}$ activities. The observations at Puna ridge imply that such vent systems can retain ${ }^{231} \mathrm{~Pa}$ and ${ }^{227} \mathrm{Ac}$, and that they are more likely to be a moderate ${ }^{227} \mathrm{Ac}$ sink than a source.

\section{Conclusions}

In the deep ocean, ${ }^{227} \mathrm{Ac}$ is mainly supplied by diffusion from the deep-sea sediments, as indicated by its vertical distribution, with a clear maximum near the bottom (on average 2.8 $\mathrm{dpm}^{\star} \mathrm{m}^{-3}$ in the bottommost $1000 \mathrm{~m}$ ), decreasing to virtually 0 in the uppermost $1000 \mathrm{~m}$ for most oceanic regions. Data from some outlets of saline water from basaltic bedrock near Hawaii indicate that no ${ }^{227} \mathrm{Ac}$ is supplied from seawater by such vent locations, in contrast to ${ }^{223} \mathrm{Ra}$. Samples from a continental slope near Puerto Rico are very low in actinium. This observation does not support the idea that continental slopes are a significant ${ }^{227}$ Ac source. Consequently, the sea floor should be the only significant actinium source for the deep ocean, and the ${ }^{227} \mathrm{Ac}$ flux from the sea-floor (about $127 \mathrm{dpm}{ }^{*} \mathrm{~m}^{-2}{ }^{*} \mathrm{y}^{-1}$ ) must support the entire ${ }^{227}$ Ac inventory (on average $4000 \mathrm{dpm}^{*} \mathrm{~m}^{-2}$ ) in the water column of open ocean regions. In the coastal ocean, average ${ }^{227} \mathrm{Ac}$ activities range from $0.4 \mathrm{dpm}^{*} \mathrm{~m}^{-3}$ (Celestun) to 3.0 $\mathrm{dpm}^{*} \mathrm{~m}^{-3}$ (Korean strait). The higher activities in the Korean Strait are associated with a 
contribution from a large shelf region (Yellow Sea), which is consistent with similar observations for ${ }^{228} \mathrm{Ra}$ (Rutgers van der Loeff et al., 1995). The average ${ }^{227}$ Ac inventory for the shelf region is $157 \mathrm{dpm}^{*} \mathrm{~m}^{-2}$. However, this value can not readily be converted into a realistic flux estimate. Horizontal exchange with the open ocean may permanently remove ${ }^{227} \mathrm{Ac}$ from the shelf system.

Locally, ${ }^{227} \mathrm{Ac}$ values can be found that greatly exceed the average open ocean concentrations, up to several tens of $\mathrm{dpm}^{*} \mathrm{~m}^{-3}$. They remain restricted to the immediate neighbourhood of end-members like estuaries or lagoons. Away from the source, activities decrease to the local coastal value.

The ground water data from Massachusetts point to a role of uranium enrichment combined with salinity changes for ${ }^{227} \mathrm{Ac}$ release in this reducing environment. Such an enrichment of a progenitor of ${ }^{227} \mathrm{Ac}\left({ }^{235} \mathrm{U}\right.$ or $\left.{ }^{231} \mathrm{~Pa}\right)$ may lead to unusually high ${ }^{227} \mathrm{Ac} /{ }^{228} \mathrm{Ra}$ or ${ }^{223} \mathrm{Ra} /{ }^{224} \mathrm{Ra}$ ratios, as was observed at the Puna ridge (Moore et al., submitted). 


\section{References}

Buesseler, K.O. et al., 1992. Determination of thorium isotopes in seawater by nondestructive and radiochemical procedures. Deep Sea Research Part A. Oceanographic Research Papers, 39(7-8): 1103-1114.

Charette, M.A. and Sholkovitz, E.R., 2006. Trace element cycling in a subterranean estuary: Part 2. Geochemistry of the pore water. Geochimica et Cosmochimica Acta, 70(4): 811-826.

Charette, M.A., Sholkovitz, E.R. and Hansel, C.M., 2005. Trace element cycling in a subterranean estuary: Part 1. Geochemistry of the permeable sediments. Geochimica et Cosmochimica Acta, 69(8): 2095-2109.

Cochran, J.K. and Krishnaswami, S., 1980. Radium, Thorium, Uranium, and ${ }^{210} \mathrm{~Pb}$ in deepsea sediments and sediment pore waters from the North Equatorial Pacific. American Journal of Science, 280: 849-889.

Geibert, W., Rutgers van der Loeff, M.M., Hanfland, C. and Dauelsberg, H.J., 2002. Actinium-227 as a deep-sea tracer: Sources, distribution and applications. Earth and Planetary Science Letters, 198 (1-2): 147-165.

Geibert, W. and Vöge, I., submitted. The measurement of ${ }^{227} \mathrm{Ac}$ on $50 \mathrm{~L}$ sea water samples. Marine Chemistry, submitted.

Gierloff-Emden, H.G., 1980. Geographie des Meeres, Teil 1, Ozeane und Küsten. Lehrbuch der Allgemeinen Geographie. Walter de Gruyter, Berlin, New York.

Gonneea, M.E., Morris, P.K., Dulaiova, H. and Charette, M.A., 2007. New perspectives on radium behavior within a subterranean estuary. Marine Chemistry, submitted.

Huisman, J., Pham Thi, N.N., Karl, D.M. and Sommeijer, B., 2006. Reduced mixing generates oscillations and chaos in the oceanic deep chlorophyll maximum. Nature, 439(7074): 322-325.

Hwang, D.W., Kim, G., Lee, Y.W. and Yang, H.S., 2005. Estimating submarine inputs of groundwater and nutrients to a coastal bay using radium isotopes. Marine Chemistry, 96(1-2): 61-71.

Kadko, D., 1996. Radioisotopic studies of submarine hydrothermal vents. Reviews of Geophysics, 34(3): 349-366.

Kim, G., Ryu, J.-W., Yang, H.-S. and Yun, S.-T., 2005. Submarine groundwater discharge (SGD) into the Yellow Sea revealed by ${ }^{228} \mathrm{Ra}$ and ${ }^{226} \mathrm{Ra}$ isotopes: Implications for global silicate fluxes. Earth and Planetary Science Letters, 237(1-2): 156-166.

Lee, Y.-W. and Kim, G., 2007. Linking groundwater-borne nutrients and dinoflagellate redtide outbreaks in the southern sea of Korea using a Ra tracer. Estuarine, Coastal and Shelf Science, 71(1-2): 309-317.

Moore, W.S., 1976. Sampling ${ }^{228} \mathrm{Ra}$ in the deep ocean. Deep Sea Research and Oceanographic Abstracts, 23(7): 647-651.

Moore, W.S. and Arnold, R., 1996. Measurement of ${ }^{223} \mathrm{Ra}$ and ${ }^{224} \mathrm{Ra}$ in coastal waters using a delayed coincidence counter. Journal of Geophysical Research C: Oceans, 101(C1): 1321-1329.

Moore, W.S., Ussler, W. and Paull, C.K., submitted. Short-lived radium isotopes in the Hawaiian margin: Evidence for large fluid fluxes through the Puna Ridge. Marine Chemistry, this volume.

Nozaki, Y., 1984. Excess ${ }^{227}$ Ac in deep ocean water. Nature, 310: 486-488.

Nozaki, Y., 1993. Actinium-227: a steady state tracer for the deep-sea basin-wide circulation and mixing studies. In: T. Teramoto (Editor), Deep ocean circulation, physical and chemical aspects. Elsevier, pp. 139-155.

Nozaki, Y., Yamada, M. and Nikaido, H., 1990. The marine geochemistry of Actinium-227: evidence for its migration through sediment pore water. Geophysical Research Letters, 17(11): 1933-1936.

Nozaki, Y. and Yang, H.-S., 1987. Th and $\mathrm{Pa}$ isotopes in the waters of the western margin of the Pacific near Japan: evidence for release of ${ }^{228} \mathrm{Ra}$ and ${ }^{227} \mathrm{Ac}$ from slope sediments. Journal of the Oceanographical Society of Japan, 43: 217-227. 
Reid, D.F., Key, R.M. and Schink, D.R., 1979. Radium, Thorium and Actinium extraction from seawater using an improved manganese-oxide-coated fiber. Earth \& Planetary Science Letters, 43: 223-226.

Rutgers van der Loeff, M.M., Key, R.M., Scholten, J., Bauch, D. and Michel, A., 1995. ${ }^{228} \mathrm{Ra}$ as a tracer for shelf water in the arctic ocean. Deep Sea Research Part II: Topical Studies in Oceanography, 42(6): 1533-1553.

Shaw, T.J. and Moore, W.S., 2002. Analysis of ${ }^{227} A c$ in seawater by delayed coincidence counting. Marine Chemistry, 78(4): 197-203.

Shellenbarger, G.G., Monismith, S.G., Genin, A. and Paytan, A., 2006. The importance of submarine groundwater discharge to the nearshore nutrient supply in the Gulf of Aqaba (Israel). Limnology and Oceanography, 51(4): 1876-1886.

Street, J.H., Knee, K.L., Grossmann, E.E. and Paytan, A., submitted. Submarine groundwater discharge and nutrient additions to the coastal zone and coral reefs of leeward Hawai'i. (submitted).

Wunsch, C., 2000. Moon, tides and climate. Nature, 405(6788): 743-744.

Yang, H.S., Nozaki, Y., Sakai, H. and Masuda, A., 1986. The distribution of ${ }^{230} \mathrm{Th}$ and ${ }^{231} \mathrm{~Pa}$ in the deep-sea surface sediments of the Pacific Ocean. Geochimica et Cosmochimica Acta, 50: 81-89.

Young, M.B. et al., submitted. Characterizing sources of groundwater to a tropical coastal lagoon in a karstic area using radium isotopes and water chemistry. Marine Chemistry(submitted). 


\section{Figure captions}

Figure 1: Global map of sample locations

Figure 2: Sample locations and salinity-actinium relationship for the data collection from Massachusetts and Rhode Island. The solid line in the map designates the $100 \mathrm{~m}$ isobath.

Figure 3: ${ }^{227} \mathrm{Ac}$ in pore water at Waquoit Bay for August and September 2006, shown with its relationship to salinity. During each time period, samples were collected over $\sim 1$ hour from fixed well points at mid-tide. Sampling was performed during the same phase of the tide in each month. The period between the two samplings was extremely dry, leading to seawater intrusion into the aquifer, which resulted in a large Ac release from the aquifer sediments.

Figure 4: Sample locations and salinity-actinium relationship for the data collection from Hawaii. Deep water samples can be identified by their constantly high salinities. Note the different scale for ${ }^{227} \mathrm{Ac}$.

Figure 5: Map of sample locations at the north western shore of Yucatan, Mexico, and the corresponding salinity-actinium relationship.

Figure 6: Map of sample locations off Puerto Rico, and the corresponding salinity-actinium relationship. The scales of both salinity and actinium were adapted to fit the small variations in the deep sea.

Figure 7: Map of sample locations in the Gulf of Aqaba, Red Sea, and the corresponding salinity-actinium relationship.

Figure 8: Map of sample locations off South Korea, and the corresponding salinity-actinium diagram.

Figure 9: Sample locations in the German Bight of the North Sea, and the corresponding salinity-actinium diagram. Salinities $<20$ indicate values from an estuary.

Figure 10: The relationship between ${ }^{227} A c_{e x}$ in open ocean regions, and the distance from the deep-sea floor, illustrated with four typical profiles. 


\section{Tables}

Table 1: Overview of average ${ }^{227}$ Ac activities of the coastal marine end member. Included are all near shore, near surface values for which salinity values were available and $>30$, and where no obvious anthropogenic influence was observed. The average at the bottom of the table was calculated from the regional averages, in order to avoid over-representation of areas with intense sampling.

\begin{tabular}{|c|c|c|c|}
\hline Location & $\begin{array}{l}\text { Average } \\
{ }^{227} \mathrm{Ac}\left[\mathrm{dpm}^{\star \mathrm{m}} \text { - }\right. \\
\left.{ }^{3}\right]\end{array}$ & $\begin{array}{l}\text { Standard } \\
\text { Deviation }\end{array}$ & $\mathrm{n}$ \\
\hline $\begin{array}{l}\text { Massachusetts } \\
\text { and Rhode } \\
\text { Island, QP }\end{array}$ & 0.9 & 0.46 & 13 \\
\hline $\begin{array}{l}\text { Massachusetts } \\
\text { and Rhode } \\
\text { Island, PR }\end{array}$ & 1.4 & - & 1 \\
\hline Hawaii & 1.0 & - & 1 \\
\hline $\begin{array}{l}\text { Yucatan, } \\
\text { Celestun }\end{array}$ & 0.4 & 0.2 & 8 \\
\hline Israel, Elat & 1.4 & 2.2 & 34 \\
\hline $\begin{array}{l}\text { South Korea, } \\
\text { Korean Strait }\end{array}$ & 3.0 & 0.6 & 12 \\
\hline $\begin{array}{l}\text { Germany, } \\
\text { North Sea }\end{array}$ & 0.5 & 0.3 & 4 \\
\hline Average & 1.2 & 0.8 & 7 (regions) \\
\hline
\end{tabular}

Table 2: Average ${ }^{227} \mathrm{Ac}_{\mathrm{ex}}$ activity in the open ocean, as derived from four typical profiles ((Nozaki, 1984), (Geibert et al., 2002).

\begin{tabular}{|c|c|}
\hline distance to seafloor $[\mathrm{m}]$ & ${ }^{227} \mathbf{A c}_{\mathrm{ex}}\left[\mathrm{dpm}^{\star} \mathbf{m}^{-3}\right]$ \\
\hline$<1000$ & 2.8 \\
\hline 1000 to $<2000$ & 1.0 \\
\hline 2000 to $<3000$ & 0.3 \\
\hline 3000 to 4000 & 0.0 \\
\hline Average activity in water column & $\mathbf{1 . 0}$ \\
\hline
\end{tabular}

